\title{
Effect of Genistein Supplementation on the Progression of Neoplasms and the Level of the Modified Nucleosides in Rats With Mammary Cancer
}

\author{
KAROLINA BANYS ${ }^{1}$, JOANNA GIEBULTOWICZ ${ }^{2}$, MARCIN SOBCZAK ${ }^{3}$, RAFAL WYREBIAK ${ }^{3}$, \\ WOJCIECH BIELECKI ${ }^{4}$, ROBERT WRZESIEN ${ }^{5}$ and BARBARA BOBROWSKA-KORCZAK ${ }^{1}$ \\ ${ }^{1}$ Department of Bromatology, Faculty of Pharmacy, Medical University of Warsaw, Warsaw, Poland; \\ ${ }^{2}$ Department of Drug Analysis, Faculty of Pharmacy, Medical University of Warsaw, Warsaw, Poland; \\ ${ }^{3}$ Department of Biomaterials Chemistry, Chair of Analytical Chemistry and Biomaterials, \\ Faculty of Pharmacy, Medical University of Warsaw, Warsaw, Poland; \\ ${ }^{4}$ Department of Pathology and Veterinary Diagnostics, Faculty of Veterinary Medicine, \\ Warsaw University of Live Sciences, Warsaw, Poland; \\ ${ }^{5}$ Central Laboratory of Experimental Animals, Medical University of Warsaw, Warsaw, Poland
}

\begin{abstract}
Background/Aim: The aim of the study was to assess the impact of nano-, micro-, and macro-sized-genistein on the growth and development of neoplasms in rats with mammary cancer. Additionally, the effect on the kinetics of changes (9-11-17-20 week of a rat's life) in the levels of methyl derivatives: 1-methyladenine, 3-methyladenine, 7methylguanine, 1-methylguanine, 1-methyladenosine, 7methylguanosine, O-methyl-guanosine and N6-methyl-2'deoxyguanosine in the urine of rats was analyzed. Materials and Methods: Female Sprague-Dawley rats divided into 4 groups were used in the study. Animals were fed only a control diet or diets supplemented with the nano-, micro- and macro-sized genistein. To induce the mammary adenocarcinoma, rats were treated with 7,12-dimethylbenz[a] anthracene (DMBA). Modified nucleosides were determined by a high-performance liquid chromatography coupled to mass spectrometry method (LC-MS/MS). Results: The supplementation of the diet of animals with genistein resulted in an increase in the excretion of methylated derivatives in the urine of rats. In the animals receiving standard diet, the levels of methyl derivatives increased during the study or remained relatively low. In the case of animals whose diet was supplemented with the various forms of
\end{abstract}

This article is freely accessible online.

Correspondence to: Barbara Bobrowska-Korczak, Ph.D., Department of Bromatology, Faculty of Pharmacy, Medical University of Warsaw, Banacha 1, 02-097 Warsaw, Poland. Tel: +48 225720785, e-mail: barbara.bobrowska@wum.edu.pl

Key Words: Genistein, nanoparticles, macroparticles. genistein, the levels of methylated derivatives were very high from the beginning. Conclusion: High levels of methyl derivatives can influence carcinogenesis.

Genistein (4',5,7-trihydroxyisoflavone or 5,7-dihydroxy-3- [4hydroxyphenyl] chromen-4-one) (C15H10O5) belongs to a multifunctional natural isoflavonoid class of flavonoids with a 15-carbon skeleton. It was isolated for the first time from Genista tinctoria L. in 1899 and named after the genus of this plant (1). Since then, it has been considered the main secondary metabolite of the Trifolium species and in Glycine max L. (synonym Soja hispida) (1). Numerous clinical studies have shown chemopreventive and therapeutic effects of genistein on various types of cancer (2). Genistein has cytostatic and cytotoxic properties on both healthy and cancerous cells. The mechanisms of these actions are associated with inhibition of the activity of tyrosine kinases transmitting cell growth signals and topoisomerase II, a protein that is responsible for DNA stability (3). In this way, genistein induces apoptosis. In addition, it has been shown to cause cell cycle arrest, antiangiogenic, antimetastatic, and anti-inflammatory effects (4). These properties are beneficial in the treatment of cancer (4). However, this action can be harmful to healthy cells. By causing DNA strand breaks in genes, it may cause mutations. Based on in vitro and in vivo tests, it has been found that genistein may also accelerate the growth of certain types of cancer, in particular those that are hormone-dependent, and reduce their sensitivity to tamoxifen and letrozole. Genistein is a phytosterol with a structure similar to $17 \beta$-estradiol (E2), which is the main estrogen in women. Thus, phytoestrogens may affect the reproductive and endocrine systems leading to the development of some estrogen-related cancers. These types 
Table I. Dynamic light scattering (DLS) results for genistein particles.

\begin{tabular}{lcccc}
\hline $\begin{array}{l}\text { DLS } \\
\text { Parameter }\end{array}$ & $\begin{array}{c}\text { Size } \\
(\mathrm{d} . n \mathrm{~nm})^{\mathrm{a}}\end{array}$ & $\begin{array}{c}\text { Z-average } \\
(\mathrm{d} . \mathrm{nm})\end{array}$ & $\begin{array}{c}\text { Zeta } \\
\text { potential }^{\mathrm{b}}[\mathrm{mV}]\end{array}$ & $\mathrm{D}^{\mathrm{c}}$ \\
\hline $\begin{array}{l}\text { Genistein } \\
\text { nanoparticles }\end{array}$ & $92 \pm 41$ & 158 & $-17.2 \pm 5.5$ & 1,000 \\
$\begin{array}{l}\text { Genistein } \\
\text { microparticles }\end{array}$ & $587 \pm 83$ & 1467 & $-30.2 \pm 6.0$ & 0,873 \\
\hline
\end{tabular}

${ }^{a}$ Size \pm standard deviation; ${ }^{b}$ zeta potential \pm standard deviation; ${ }^{\mathrm{c}}$ dispersity.

of cancers include cervical cancer, breast cancer or ovarian cancer (5-8). In addition, studies have shown that high levels of flavonoids in the diet of pregnant women are associated with an increased risk of acute myeloid leukemia (AML) in infants, representing about $15 \%$ of the total infant incidence of leukemia in USA (9).

It has been suggested for many years that modified nucleosides may be tumor markers, as their levels are often elevated in patients with oncogenic disease (10-13). It has been shown that they contribute along with genetic mutations to cancer development and progression. It was found that increased gene expression may be caused by increased methylation of N-7 guanine (7-MeG) in methyl-CpG pairs, which may result in a change in protein/DNA interactions and chromatin remodeling (14). Moreover, the majority of lesions created by alkylating agents, such as 3-methyladenine (3-MeA), strongly block replication (15-17). Genistein might modulate the DNA methylation status and expression of cancer-related genes in breast cancer cells $(18,19)$. However, the precise mechanisms underlying the effect of genistein on breast cancer development, in particular the epigenetic mechanisms, remain unclear. Therefore, further studies are needed to determine the beneficial and harmful effects of genistein, as well as to determine the mechanism of action of genistein, the safe therapeutic doses, and the administration form.

The aim of the present research was to assess the impact of nano-, micro- and macro-sized-genistein on the growth and development of neoplasms in rats with mammary cancer (adenocarcinoma) induced with 7,12dimethylbenz[a]anthracene. Additionally, we aimed to examine the effect on the kinetics of changes (9-11-17-20 week of a rat's life) in the levels of the methyl derivatives: 1-methyladenine, 3-methyladenine, 7-methylguanine, 1methylguanine, 1-methyladenosine, 7-methylguanosine, Omethyl-guanosine, N6-methyl-2'-deoxyguanosine in the urine of rats with mammary cancer (adenocarcinoma) induced with 7,12-dimethylbenz[a]anthracene. The studies of the impact of dietary components on the growth and development of neoplasms and on selected biomarkers can be very important in both cancer prevention and treatment.

\section{Materials and Methods}

Preparation of genistein micro- and nanoparticles. PVA ( $\mathrm{n}=$ approx. 2,000 , degree of saponification ca. $80 \mathrm{~mol} \%$ ) and genistein (purity $>98.0 \%$ ) were purchased from Tokyo Chemical Industries (Portland, OR, USA). Ethyl acetate (purity 99.8\%) was purchased from Avantor Performance Materials Poland S.A (Gliwice, Poland).

Scientz JY-92 - IIDN 900 Watt (Staufen, Germany) ultrasonic homogenizer with $6 \mathrm{~mm}$ titanium tip was used for homogenization. Homogenization parameters were as follows: $15 \mathrm{~min}$ homogenization time, $4.5 \mathrm{~s}$ pulse, $0.5 \mathrm{~s}$ pulse interval, $75 \%$ power.

To a strongly stirred $(5,488 \mathrm{RCF}) 2.5 \%$ PVA solution $(400 \mathrm{ml}$, saturated with ethyl acetate), concentrated solution of genistein (1.00 g) in ethyl acetate was added dropwise. Stirring was continued for 5 min after addition. Opaque solution was ho-mogenized for $15 \mathrm{~min}$ and slowly stirred $(900 \mathrm{rpm})$ with gentle heating at $40^{\circ} \mathrm{C}$. Homogenization was repeated every $24 \mathrm{~h}$ until complete removal of ethyl acetate. The mixture was diluted $3 \times$ with distilled water and centrifuged $(15 \mathrm{~min}$, 4,500 rpm). Resulting nanoparticles were repeatedly washed with distilled water and centrifuged until removal of excess PVA, and dried at room temperature in vacuum for $24 \mathrm{~h}$. The above procedure yielded $1.02 \mathrm{~g}$ of nanoparticles. Micronized genistein was prepared by milling in SPEX Sample Prep 6770 Freezer/Mill cryogenic mill (Retsch Polska Verder Polska Sp. z o.o., Katowice, Poland) (coolant: liquid nitrogen, 3 cycles, precool time: $1 \mathrm{~min}$, run time: $2 \mathrm{~min}$, cool time: 1 min, rate: $15 \mathrm{CPS}$ ). Macro-size genistein was used as received.

To examine the average size and zeta potential of the particles the dynamic light scattering technique (DLS) was applied. The Zetasizer Nano ZS instrument (Malvern Instruments, Westborough, MA, USA) equipped with a red laser with a wavelength of $633 \mathrm{~nm}$ and a scattering angle of $173^{\circ}$ at $25^{\circ} \mathrm{C}$ was utilized for this purpose. Sample was suspended in either distilled water (Zeta potential measurement) or glycerol water solution (size measurement) (Table I, Figures 1 and 2).

Laboratory animals. Female Sprague-Dawley rats $(n=32)$ were obtained from the Animal Laboratory, Department of General and Experimental Pathology, Medical University of Warsaw. The study was approved by the Ethics Committee. All rats were provided Labofeed H standard diet (standard diet: Labofeed H, Żurawia 19, 89-240 Kcynia, Poland) and water ad libitum and housed in an environmentally controlled room at $22^{\circ} \mathrm{C}$ with a 12 -h light-dark cycle. The rats were divided into four experimental groups: control animals were fed only standard diet (without supplementation) (received $0.4 \mathrm{ml}$ water), nanosized genistein $(0.1 \mathrm{mg} / \mathrm{ml}$; i.e., 0.2 $\mathrm{mg} / \mathrm{kg} . \mathrm{bw})(92 \pm 41 \mathrm{~nm})$, microsized genistein $(0.1 \mathrm{mg} / \mathrm{ml}$; i.e. 0.2 $\mathrm{mg} / \mathrm{kg} . \mathrm{bw})(587 \pm 83)$ and macrosized genistein $(0.1 \mathrm{mg} / \mathrm{ml}$; i.e. 0.2 $\mathrm{mg} / \mathrm{kg} . \mathrm{bw})$ supplemented groups. The rats were fed extra supplements suspended in water $(0.4 \mathrm{ml}$ daily via gavage), from 40 days until 20 weeks of age. The polyphenols dose level was selected based on human average daily consumption (extrapolating on the rats' body weight). Determining the effect of a selected dose of genistein may allow its application in human cancer prevention or in the improvement of pharmacological treatment.

The rats were treated twice with DMBA (7,12-dimethyl-1,2benz(a)anthracene; Sigma-Aldrich, St. Louis, MO, USA) in rapeseed oil (via gavage) to induce mammary cancer (adenocarcinoma); the first treatment was given at 60 days of age ( $80 \mathrm{mg} / \mathrm{kg}$ body weight); followed by a repeated dose of $40 \mathrm{mg} / \mathrm{kg}$ body weight at 90 days of rat age. 
Size distribution by intensity

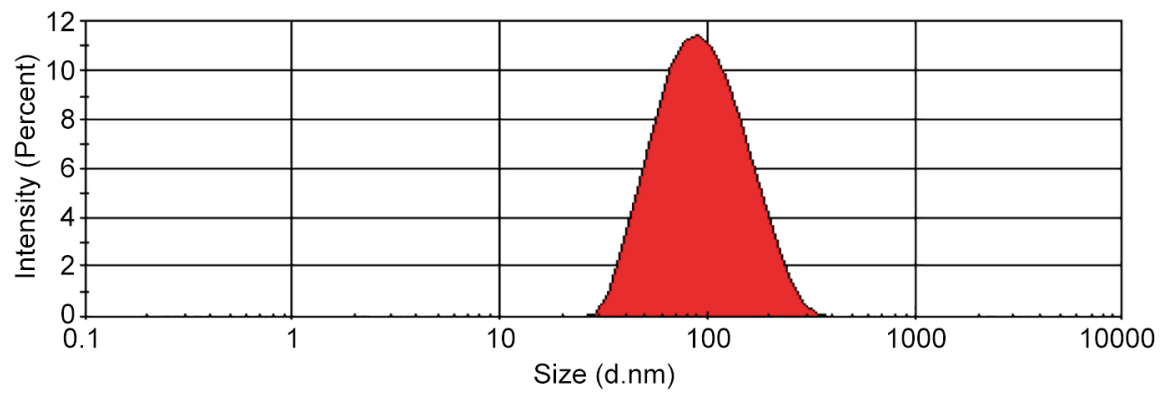

Figure 1. Dynamic light scattering size distribution graph for synthesized nanoparticles.

Size distribution by intensity

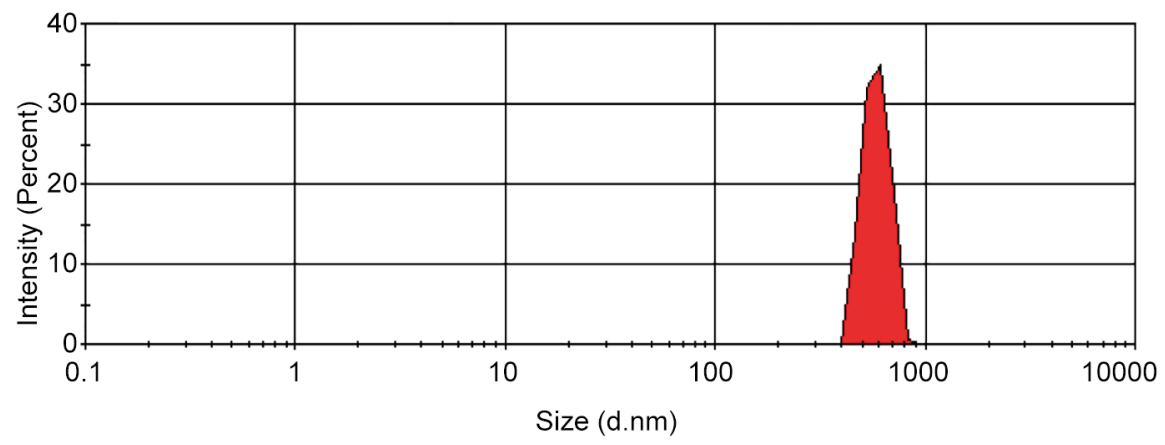

Figure 2. Dynamic light scattering size distribution graph for synthesized microparticles.

The animals were examined by palpation during the study to characterize the time course of tumor development. In order to obtain urine samples, each animal was individually placed in a metabolic cage for $24 \mathrm{~h}$. Urine samples were collected once a week at the $9^{\text {th }}, 11^{\text {th }}, 17^{\text {th }}, 20^{\text {th }}$ week of rodent's age and stored at $-70^{\circ} \mathrm{C}$ until the test time.

Histopathology. The rats were sacrificed by decapitation at 150 days of age, and tumors were evaluated histopathologically. The tissues were placed in a buffered formalin solution, dehydrated, sealed in paraffin and cut into $4 \mu \mathrm{m}$ thick sections. Hematoxylin and eosin staining of tissue and cell sections was applied, and the sections were evaluated using a BX43 Olympus research microscope (Olympus Europa SE \& Co., Hamburg, Germany).

LC-MS/MS analysis. Reference standards i.e., 1-methyladenine, 3methyladenine, 7-methylguanine, 1-methylguanine, 1-methyladenosine, 7-methylguanosine, O-methyl-guanosine, N6-methyl-2'-deoxyguanosine as well as internal standard (tubercidin) were purchased from Sigma Aldrich. Modified nucleosides and nucleobases were determined by validated high performance liquid chromatography coupled to mass spectrometry (LC-MS/MS) method using multiple reaction monitoring (MRM) mode on Agilent 1260 Infinity (Agilent Technologies, Santa Clara, CA, USA) coupled to QTRAP 4000 (AB Sciex, Framingham, MA, USA). MRM transitions, declustering potential (DP), and collision energy (CE) for O-methylguanosine, 1-methyladenosine, 7- methylguanosine, 7-methylguanine, 3-methyladenine, 1-methylguanine and N6-methyl-2-deoxyadenosine were: (m/z) 298>152 (DP=51 V, $\mathrm{CE}=17 \mathrm{~V}), 282>55(\mathrm{DP}=66 \mathrm{~V}, \mathrm{CE}=87 \mathrm{~V}), 298>166(\mathrm{DP}=71 \mathrm{~V}$, $\mathrm{CE}=19 \mathrm{~V}), 166>79(\mathrm{DP}=96 \mathrm{~V}, \mathrm{CE}=43 \mathrm{~V}), 150>123(\mathrm{DP}=86 \mathrm{~V}$, $\mathrm{CE}=31 \mathrm{~V}), 166>135(\mathrm{DP}=81 \mathrm{~V}, \mathrm{CE}=31 \mathrm{~V})$ and 266>150 (DP=61 V, $\mathrm{CE}=23 \mathrm{~V})$, respectively. Chromatographic separation was achieved using SeQuant ${ }^{\circledR}$ ZIC $^{\circledR}$-HILIC $(50 \times 2.1 \mathrm{~mm}, 5 \mu \mathrm{m}$, Merck KGaA, Darmstadt, Germany) column. The column was maintained at $25^{\circ} \mathrm{C}$ at the flow rate of $0.5 \mathrm{ml} / \mathrm{min}$. The mobile phases consisted of $20 \mathrm{mM}$ ammonium acetate as the eluent $\mathrm{A}$ and acetonitrile with $0.2 \%$ formic acid as the eluent B. The gradient (\%B) was as follows: 0 min, 95\%; 1 $\min , 95 \%$; $7 \mathrm{~min}, 50 \%$; $8 \mathrm{~min}, 50 \%$. The injection volume was $5 \mu \mathrm{l}$. Urine samples $(0.1 \mathrm{ml})$ prior to injection to $\mathrm{LC}$ were mixed with tubercidin $(0.1 \mathrm{ml}, 1 \mu \mathrm{g} / \mathrm{ml})$ and acetonitrile $(0.6 \mathrm{ml})$, vortexed in high speed $(3 \mathrm{~min})$ and centrifuged $(5 \mathrm{~min}$ at $10,000 \times \mathrm{g}$ ).

The levels of the modified nucleosides and bases in urine were standardized by conversion to the creatinine level. The latter was determined in urine samples with a creatinine test (Hydrex, Warsaw, Poland) based on Jaffe's reaction.

Statistical analyses. Statistical analyses were performed using the PQStat statistical package, version 1.8.0.324 (BioInforStats, Cracow, Poland). For normally distributed data, Student's test and ANOVA were used. The results obtained in each group were compared using the analysis of variance and the post-hoc Tukey test. The test probability at the level of $p<0.05$ was assumed as 
in vivo $35: 2059-2072(2021)$

Table II. Tumour induction in 7,12-dimethylbenz[a]anthracene treated groups in relation to supplementation.

\begin{tabular}{|c|c|c|c|c|c|c|}
\hline Supplementation & $\begin{array}{c}\text { The week } \\
\text { when first tumor } \\
\text { occurred }\end{array}$ & $\begin{array}{l}\text { Number of tumors } \\
\text { per animal } \\
\text { (week 20) }\end{array}$ & $\begin{array}{l}\text { Tumor incidence (\%) } \\
\text { (week 20) }\end{array}$ & $\begin{array}{c}\text { Tumor weight }(\mathrm{g}) \\
(\text { week } 20) \\
\text { mean } \pm \text { SD }\end{array}$ & Tumor grade & $\begin{array}{c}\text { The mean number } \\
\text { of mitoses in the field } \\
\text { of view area* }\end{array}$ \\
\hline Standard & $16(2 / 8)$ & $(2-9)$ & $100 \%(8 / 8)$ & $\begin{array}{c}0.93 \pm 1.34 \\
(0.10-7.80)^{\mathrm{a}}\end{array}$ & $\begin{array}{c}\text { Adenocarcinoma } \\
2 \text { grade }\end{array}$ & $1.79 \pm 1.25^{\mathrm{a}, \mathrm{b}, \mathrm{c}}$ \\
\hline Macrogenistein & $17(5 / 8)$ & $(1-6)$ & $100 \%(8 / 8)$ & $\begin{array}{c}1.27 \pm 1.52 \\
(0.14-6.39)\end{array}$ & $\begin{array}{c}\text { Adenocarcinoma } \\
2 \text { grade }\end{array}$ & $4.46 \pm 2.38^{\mathrm{a}, \mathrm{d}}$ \\
\hline Microgenistein & $17(1 / 8)$ & $(0-3)$ & $88 \%(7 / 8)$ & $\begin{array}{c}1.99 \pm 1.75 \\
(0.11-6.11)^{\mathrm{a}}\end{array}$ & $\begin{array}{c}\text { Adenocarcinoma } \\
3 \text { grade }\end{array}$ & $7.33 \pm 1.57^{\mathrm{b}, \mathrm{d}}$ \\
\hline Nanogenistein & $14(1 / 8)$ & $(2-5)$ & $100 \%(8 / 8)$ & $\begin{array}{c}1.59 \pm 2.64 \\
(0.06-9.50)\end{array}$ & $\begin{array}{c}\text { Adenocarcinoma } \\
3 \text { grade }\end{array}$ & $5.82 \pm 1.57^{\mathrm{c}}$ \\
\hline
\end{tabular}

Data are expressed as mean \pm SD. Values sharing letters (a: standard, b: macro genistein, c: micro genistein, d: nano genistein) indicate statistically significant differences between groups $(p<0.01)$. *Mitoses were counted in slides from randomly selected tumors in 15 fields of view with a $40 \times$ objective magnification. SD: Standard deviation.

Table III. Tumor incidence (weeks 14-20) (\%) (number of animals that developed tumors).

\begin{tabular}{|c|c|c|c|c|c|c|c|}
\hline \multirow[b]{2}{*}{ Supplementation } & \multicolumn{7}{|c|}{ Tumor incidence $(\%)$} \\
\hline & Week 14 & Week 15 & Week 16 & Week 17 & Week 18 & Week 19 & Week 20 \\
\hline Standard & $0 / 8$ & $0 / 8$ & $2 / 8(25 \%)$ & $5 / 8(63 \%)$ & $6 / 8(75 \%)$ & $7 / 8(88 \%)$ & $8 / 8(100 \%)$ \\
\hline Macrogenistein & $0 / 8$ & $0 / 8$ & $0 / 8$ & $5 / 8(63 \%)$ & $6 / 8(75 \%)$ & $8 / 8(100 \%)$ & $8 / 8(100 \%)$ \\
\hline Microgenistein & $0 / 8$ & $0 / 8$ & $0 / 8$ & $1 / 8(13 \%)$ & $3 / 8(38 \%)$ & $4 / 8(50 \%)$ & $7 / 8(88 \%)$ \\
\hline Nanogenistein & $1 / 8(13 \%)$ & $1 / 8(13 \%)$ & $1 / 8(13 \%)$ & $2 / 8(25 \%)$ & $4 / 8(50 \%)$ & $6 / 8(75 \%)$ & $8 / 8(100 \%)$ \\
\hline
\end{tabular}

statistically significant, and the test probability at the level of $p<0.01$ was assumed as highly significant.

\section{Results}

Tumor size assessment. Histopathological examination revealed that chemically induced DMBA tumors were breast adenoma. Additionally, the time at which the first tumors appeared, the number and size of tumors and the incidence of cancer in rats were analyzed. The results of tumor induction in 7,12-dimethylbenz[a]anthracene treated groups in relation to supplementation are shown in Tables II and III. In the case of rats that were not supplemented and received a standard diet, the incidence of cancer was $100 \%$, the weight of tumors was in the range $0.1-7.8 \mathrm{~g}(0.93 \pm 1.34)$ and the number of tumors per rat ranged from 2 to 9 (Table II). Similar results were obtained in the case of rats supplemented with macrosized genistein [incidence $100 \%$, tumors weight $1.27 \pm 1.52 \mathrm{~g}(0.14-6.39 \mathrm{~g})$, number of tumors per rat 1-6]. In contrast, in case of animals supplemented with microgenistein, although the first tumors appeared at week 17, a week later compared to animals receiving only the standard diet, the incidence of tumors was $88 \%$, the number of tumors per rat ranged from 0 to 3 ; there was a statistically significant stimulation of tumor growth. The mean mass of the tumors in the animals receiving microgenistein was statistically significantly higher compared to tumors of animals receiving standard diet, $1.99 \pm 1.75 v s .0 .93 \pm 1.34$. In the case of animals supplemented with nanogenistein, the first tumors appeared as early as at 14 weeks of animals' age, 2 weeks earlier than in animals receiving only the standard diet, and 3 weeks earlier than in animals receiving macro and microgenistein. In the case of animals supplemented with nanogenistein, the incidence was $100 \%$, the number of tumors per rat was 2-5 and the weight of tumors at the end of the experiment was $1.59 \pm 2.64 \mathrm{~g} \quad$ (range=0.06-9.50 g). Histopathological examination showed that all examined tumors had features of breast cancer. In animals receiving only a standard, nonsupplemented diet and animals supplemented with macrogenistein, grade II adenoma was found (Figure 3, Table II). Interestingly, in samples obtained from animals supplemented with microgenistein and nanogenistein, the adenoma image indicated grade III malignancy. In the case of animals supplemented with genistein massive (increased) tumor cell proliferation was observed. The tendency of neoplastic cells to proliferate was evidenced by the number of 
A

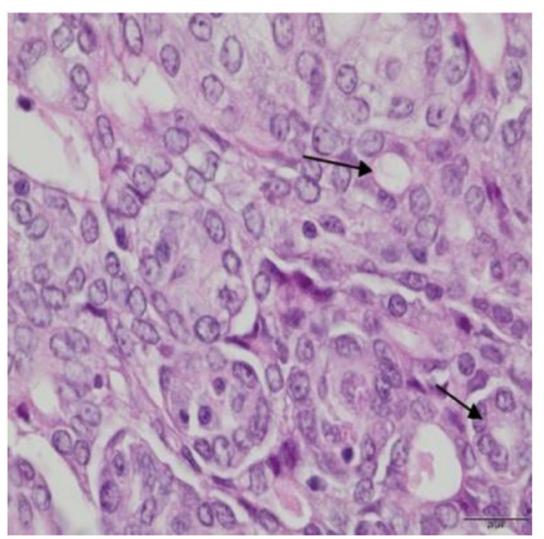

C

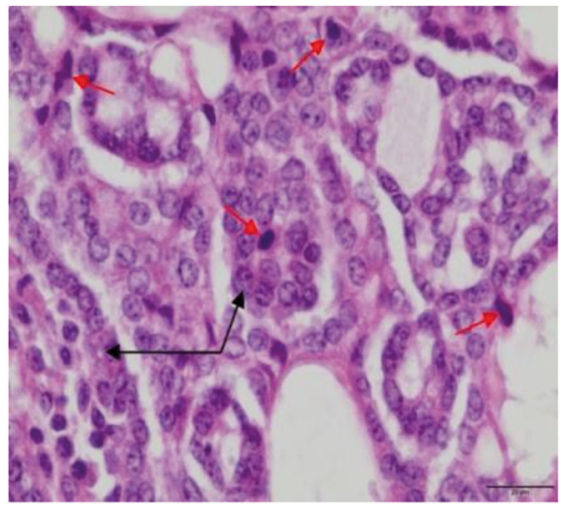

B

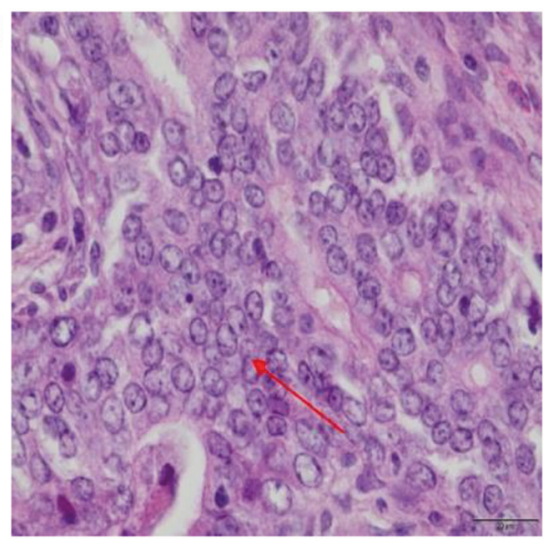

D

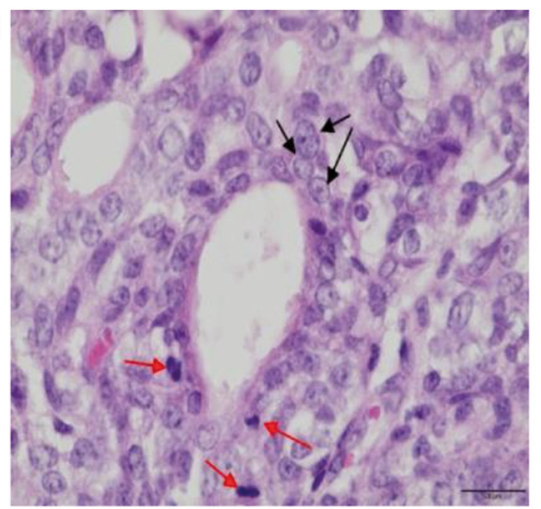

Figure 3. Hematoxylin-eosin-stained sections of breast tumors. A) rats fed with a standard diet - no supplementation (black arrows show the tubular system of tumor cells); B) rats fed with nano-genistein (red arrow indicates infiltrating tumor cell); C) rats fed with a diet supplemented with microgenistein (red arrows indicate mitosis and black bands indicate tumor cells); D) rats fed with a diet supplemented with macro-genistein (red arrows show mitosis and black arrows show cancer cells forming vesicles).

Table IV. Weight gain of rats $(g)$.

\begin{tabular}{lcccc}
\hline & \multicolumn{4}{c}{ Group } \\
\cline { 2 - 5 } & Standard & Macro & Micro & Nano \\
\hline Arithmetic mean & 99.0000 & 99.1250 & 107.4000 & 96.5000 \\
Standard deviation & 10.9414 & 8.8227 & 8.5370 & 8.7178 \\
$\begin{array}{l}\text { Standard error } \\
\text { of the mean }\end{array}$ & 3.8684 & 3.1193 & 3.0183 & 3.0822 \\
ANOVA & & & & \\
\hline
\end{tabular}

mitoses in the field of view of the microscope (at $40 \times$ lens magnification). The mean number of mitoses in the field of view (at 40x magnification of the microscope objective) in the group of rats fed with the diet without supplementation was $1.79 \pm 1.25$. In the group of rats fed with the diet supplemented with nanogenistein, microgenistein and macrogenistein the mean number of mitoses was $5.82 \pm 1.57,7.33 \pm 1.57$, and $4.46 \pm 2.38$, respectively.

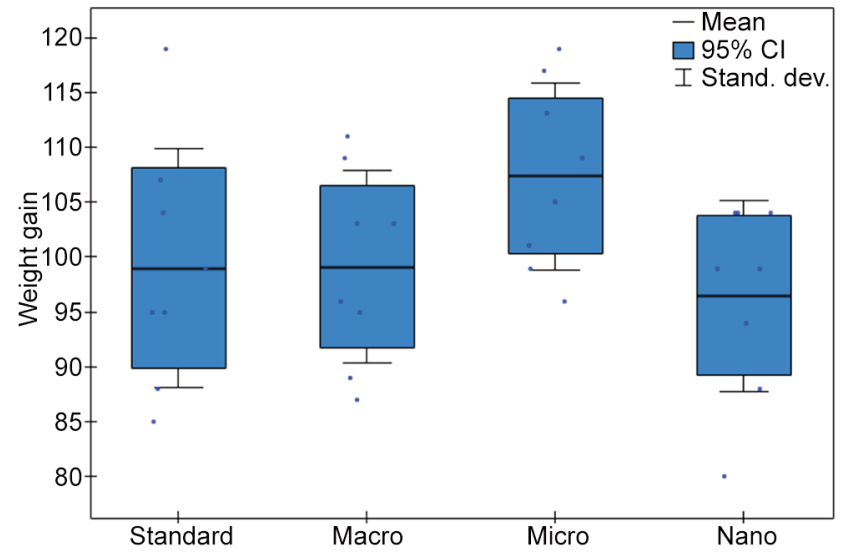

Figure 4. Weight gain of rats at week $20(\mathrm{~g})$.

Weight gain of rats. No statistically significant differences were observed in the weight gain of rats during the study period (Table IV, Figure 4). 
Table V. The results of the weight of rat liver and spleen ( $g$ ) after decapitation.

\begin{tabular}{|c|c|c|c|c|c|c|c|c|}
\hline & \multicolumn{4}{|c|}{ Liver } & \multicolumn{4}{|c|}{ Spleen } \\
\hline & Standard & Macro & Micro & Nano & Standard & Macro & Micro & Nano \\
\hline Arithmetic mean & 6.6763 & 7.6588 & 7.3413 & 7.2613 & 0.5963 & 0.7925 & 0.6663 & 0.7525 \\
\hline Standard deviation & 0.8071 & 0.7510 & 0.6076 & 0.7137 & 0.1346 & 0.2630 & 0.1838 & 0.2988 \\
\hline $\begin{array}{l}\text { Standard error } \\
\text { of the mean }\end{array}$ & 0.2854 & 0.2655 & 0.2148 & 0.2523 & 0.0476 & 0.0930 & 0.0650 & 0.1056 \\
\hline ANOVA & \multicolumn{4}{|c|}{$\mathrm{F}=2.5662, p=0.0745$} & \multicolumn{4}{|c|}{$\mathrm{F}=1.1765, p=0.3364$} \\
\hline
\end{tabular}

Organs' weight. No statistically significant differences were observed in rat liver and spleen weights (Table V, Figures 5 and 6).

Kinetic evaluation of methyl derivatives. In this study, the effect of nano-, micro- and macro-sized-genistein on the kinetics $\left(9^{\text {th }} 11^{\text {th }}, 17^{\text {th }}, 20^{\text {th }}\right.$ week of a rat's life $)$ of change in the levels of the methyl derivatives: 1-methyladenine, 3methyladenine, 7-methylguanine, 1-methylguanine 1methyladenosine, 7-methylguanosine, O-methyl-guanosine, N6-methyl-2'-deoxyguanosine in urine of rats with mammary cancer (adenocarcinoma) induced with 7,12dimethylbenz[a]anthracene, were analyzed (Figures 7, 8, 9, $10,11,12,13$ and 14).

The effect of nano-, micro- and macro-genistein on the kinetics of changes $\left(9^{\text {th }}, 11^{\text {th }}, 17^{\text {th }}, 20^{\text {th }}\right.$ week of rat's life) in the level of $\mathrm{O}$-methylguanosine ( $\mathrm{ng} / \mathrm{mg}$ creatinine) in the urine of rats treated DMBA. Highly significant $(p<0.0001)$ differences between the groups and between measurement dates $(p=0.0043)$ were found. In the case of rats, which received a standard diet, the concentration of $\mathrm{O}$ methylguanosine in the urine increased significantly $(p=0.0039)$ over time (week $9 \rightarrow 20$ ) as the cancer develops. However, in the case of animals supplemented with genistein, the levels of methylated derivatives were very high from the beginning and only in the case of microgenistein supplementation it decreased statistically significantly $(p=0.007)$ (Figure 7).

The effect of nano-, micro- and macro-genistein on the kinetics of changes $\left(9^{\text {th }}, 11^{\text {th }}, 17^{\text {th }}, 20^{\text {th }}\right.$ week of rat's life) in the levels of 3-methyladenine ( $\mathrm{ng} / \mathrm{mg}$ creatinine) in the urine of rats treated with DMBA. There was no significant ( $p=0.0873$ ) difference between the groups, whereas highly significant differences $(p<0.0001)$ were found between the measurement dates. Compared to the control group, where the concentration of the biomarker in all weeks was maintained at the same level, a decrease in the concentration of 3 methyladenine was observed in rats supplemented with macrogenistein from the $11^{\text {th }}$ to the $17^{\text {th }}$ week $(p=0.04)$ and

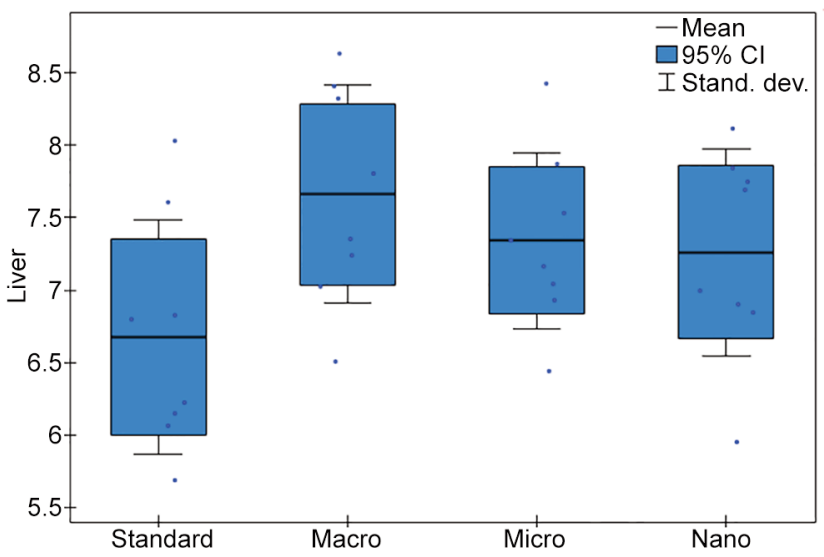

Figure 5. The results of the weight of rat liver at week $20(\mathrm{~g})$.

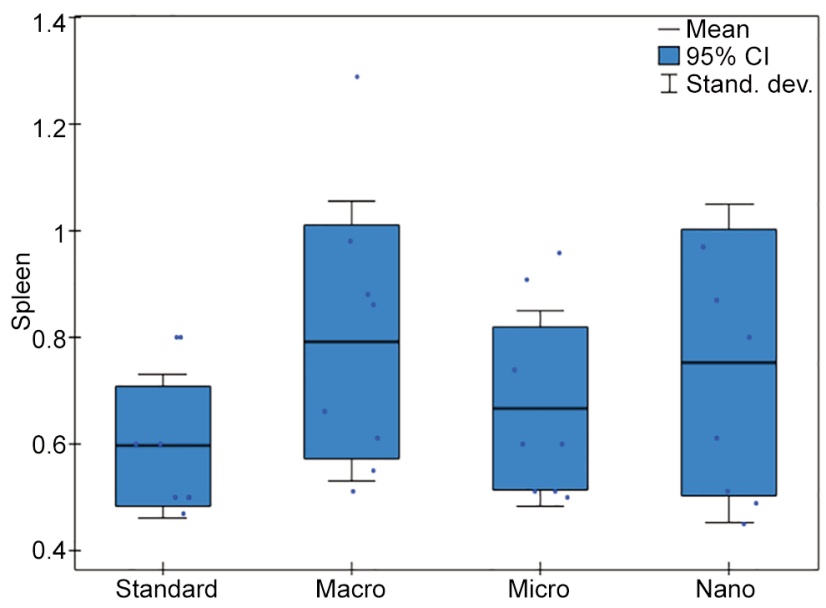

Figure 6. The results of the weight of rat spleen at week $20(\mathrm{~g})$.

at the $20^{\text {th }}$ week $(p=0.006)$. Moreover, a decrease in the concentration of the investigated methyl derivative was observed in the group supplemented with microgenistein between weeks 9 and $20(p=0.003)$ and 11 and $20(p=0.01)$. A significant decrease in the concentration of 3- 


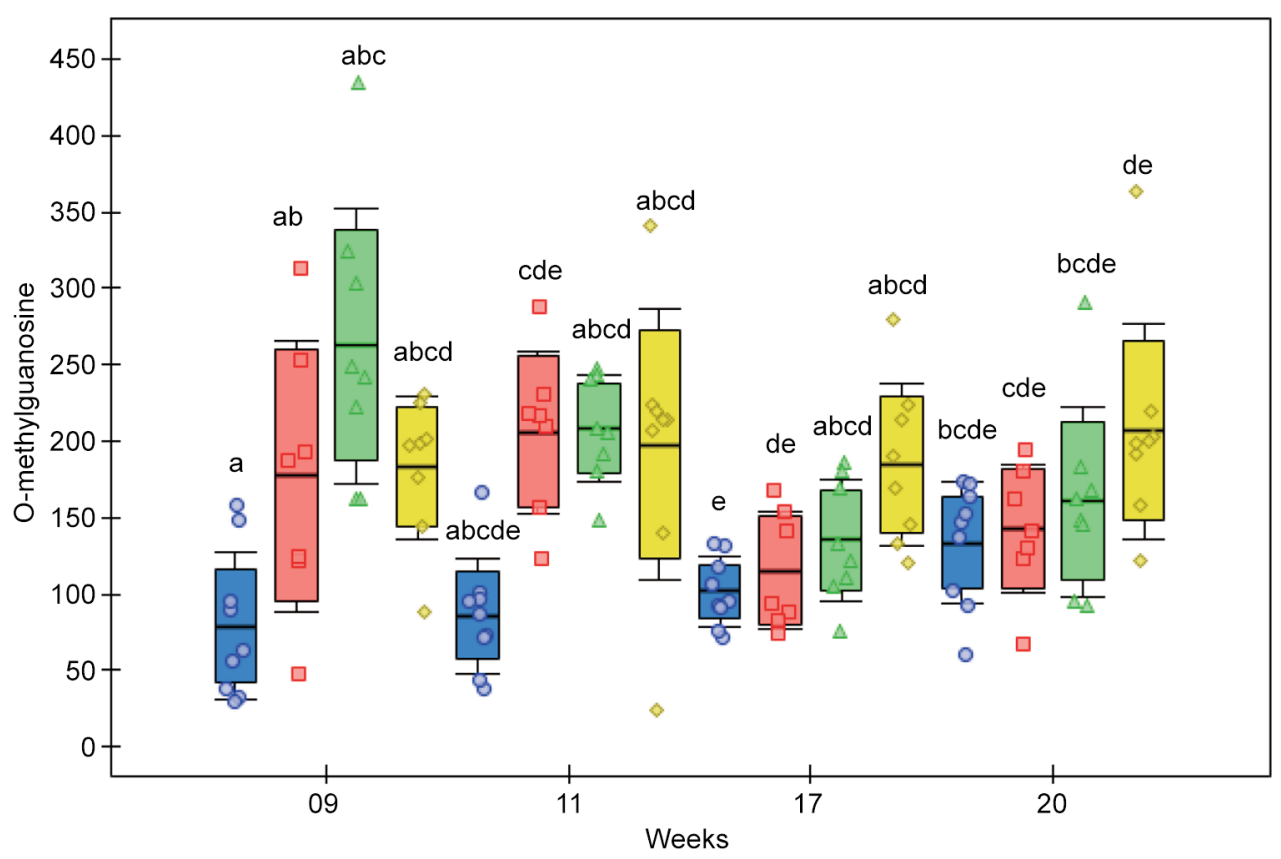

Figure 7. The effect of nano-, micro- and macro-genistein on the kinetics of changes $\left(9^{\text {th }}, 11^{\text {th }}, 17^{\text {th }}, 20^{\text {th }}\right.$ week of rat's life) in the levels of $O$ methylguanosine (ng/mg creatinine) in the urine of rats treated DMBA. Standard: - blue circles, Macro: red squares, Micro: green triangles, Nano: yellow diamonds. The same letter over two averages means no significant difference between them $(p>0.05)$; if in two compared averages the letter is not repeated, then the averages differ significantly $(p<0.05)$. The results obtained in each group were compared using analysis of variance and the post-hoc Tukey test.

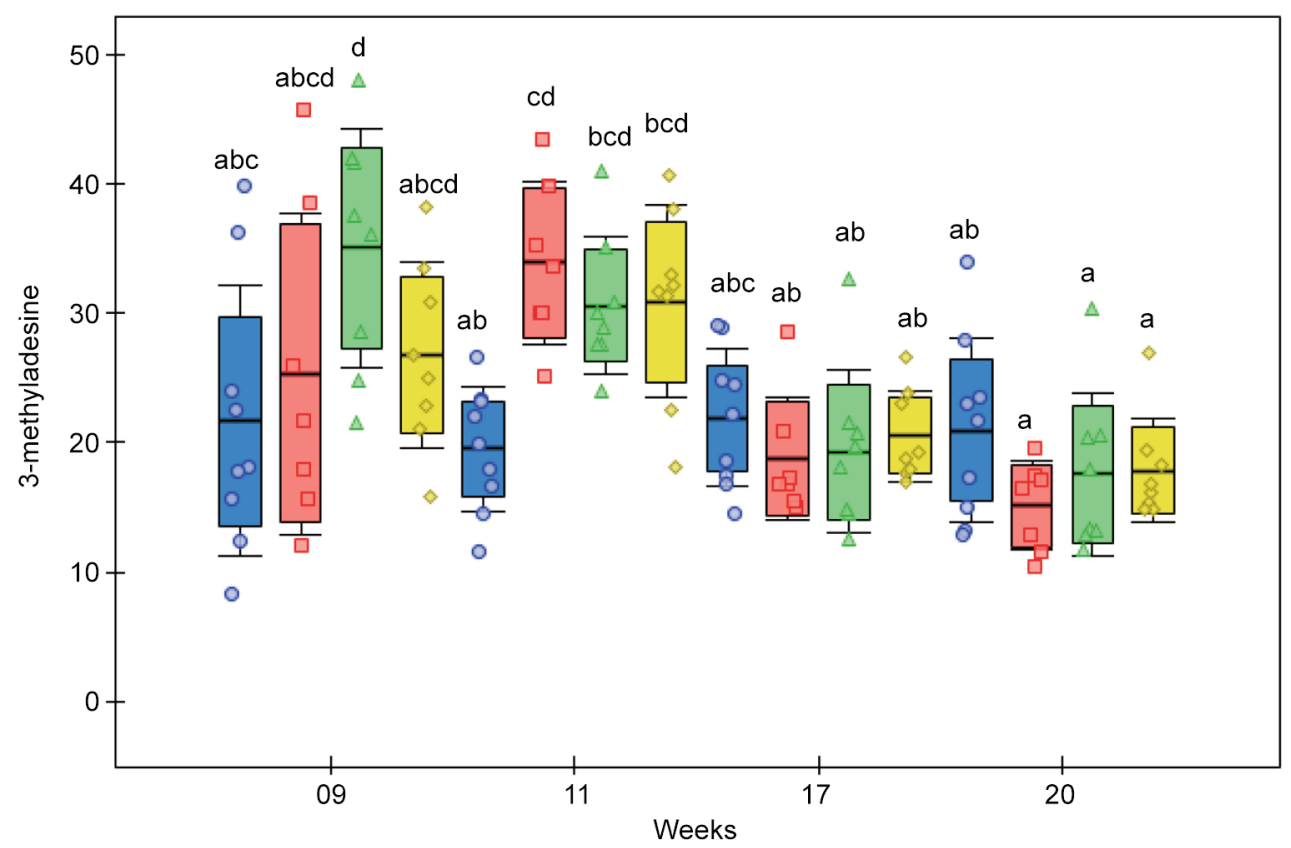

Figure 8. The effect of nano-, micro- and macro-genistein on the kinetics of changes $\left(9^{\text {th }}, 11^{\text {th }}, 17^{\text {th }}\right.$, $20^{\text {th }}$ week of rat's life) in the levels of 3 methyladenine (ng/mg creatinine) in the urine of rats treated DMBA. Standard: blue circles, Macro: red squares: Micro: green triangles, Nano: yellow diamonds. The same letter over two averages means no significant difference between them ( $p>0.05)$; if in two compared averages the letter is not repeated, then the averages differ significantly $(p<0.05)$. The results obtained in each group were compared using analysis of variance and the post-hoc Tukey test. 


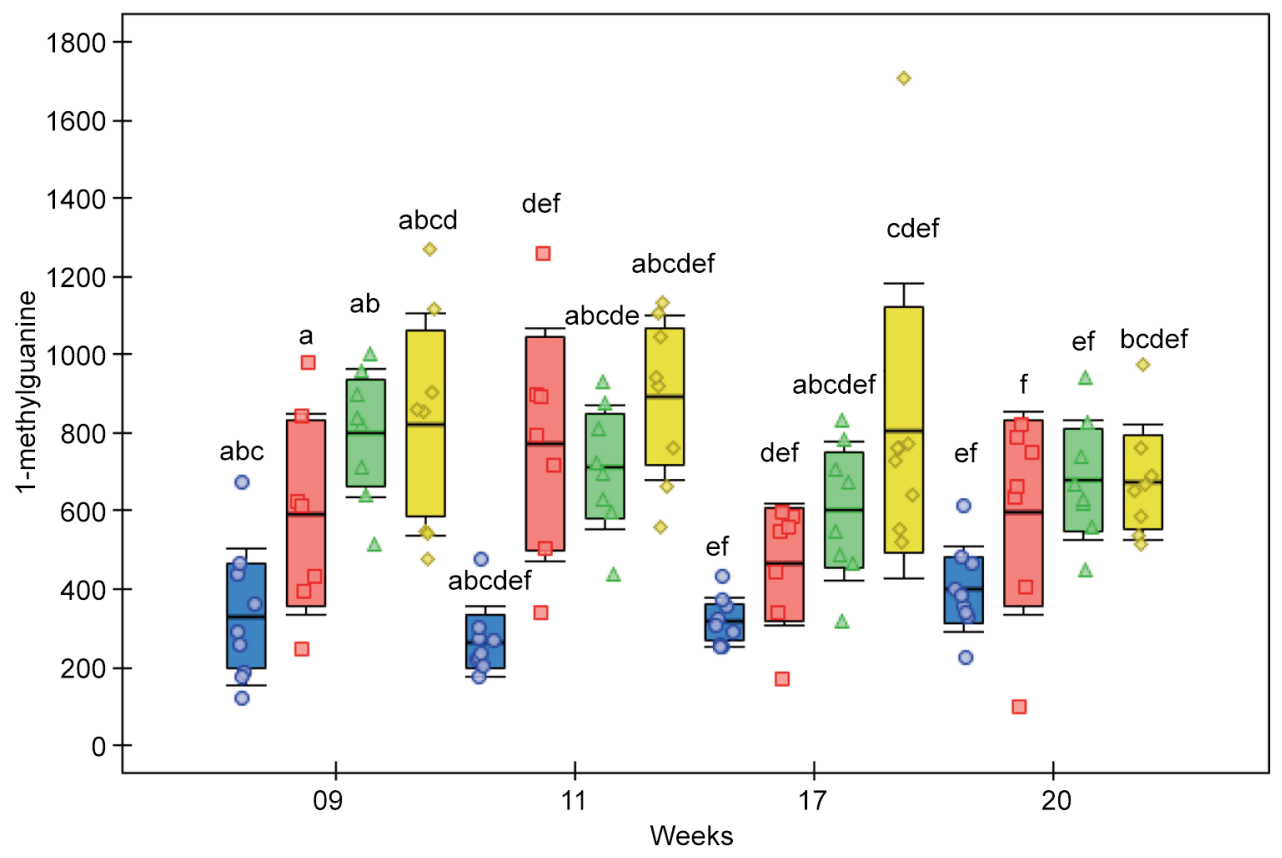

Figure 9. The effect of nano-, micro- and macro-genistein on the kinetics of changes $\left(9^{\text {th }}, 11^{\text {th }}, 17^{\text {th }}, 20^{\text {th }}\right.$ week of rat's life) in the levels of 1methylguanine ( $\mathrm{g} / \mathrm{mg}$ creatinine) in the urine of rats treated DMBA. Standard: blue circles, Macro: red squares, Micro: green triangles, Nano: yellow diamonds. The same letter over two averages means no significant difference between them ( $p>0.05)$; if in two compared averages the letter is not repeated, then the averages differ significantly $(p<0.05)$. The results obtained in each group were compared using analysis of variance and the post-hoc Tukey test.

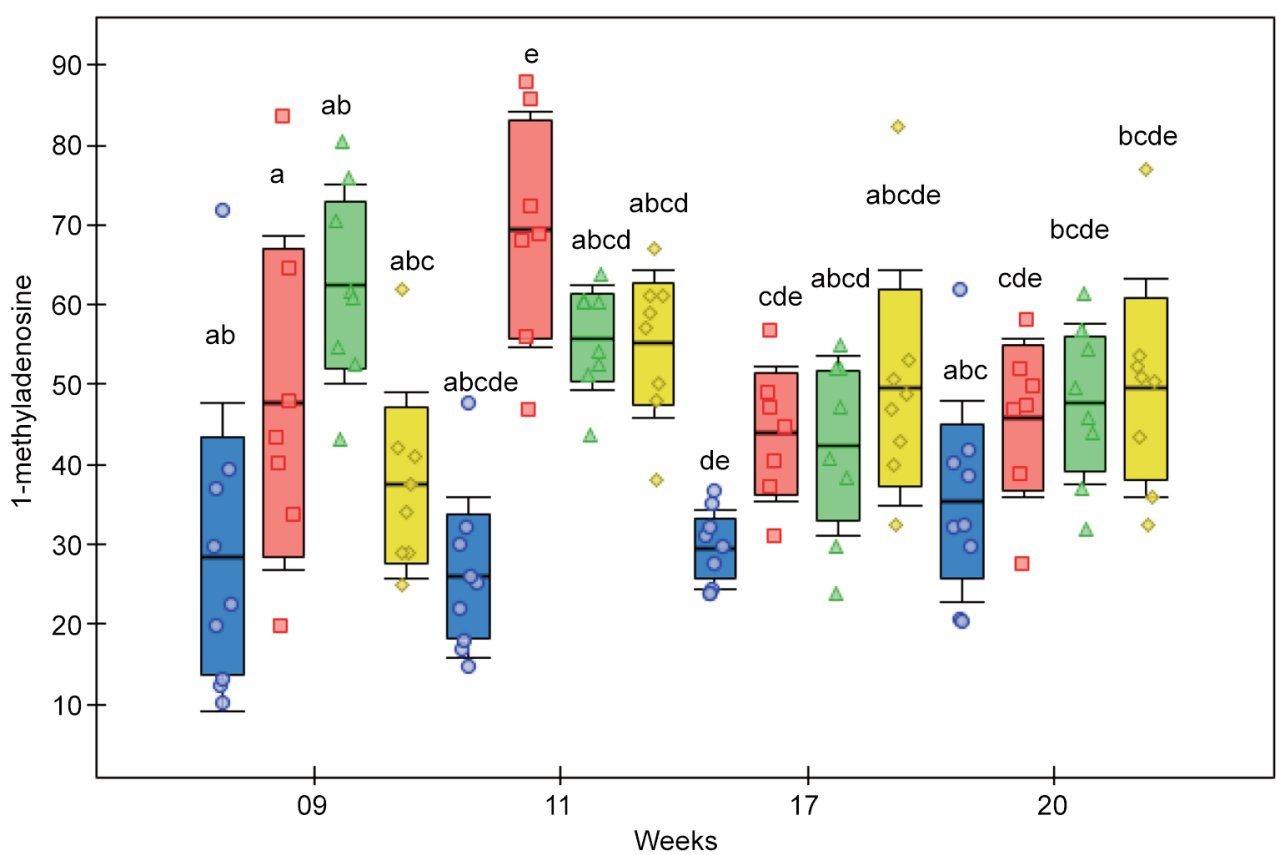

Figure 10. The effect of nano-, micro- and macro-genistein on the kinetics of changes $\left(9^{\text {th }}, 11^{\text {th }}, 17^{\text {th }}\right.$, $20^{\text {th }}$ week of rat's life) in the levels of 1 methyladenosine ( $\mu \mathrm{g} / \mathrm{mg}$ creatinine) in the urine of rats treated DMBA. Standard: blue circles, Macro: red squares, Micro: green triangles, Nano: yellow diamonds. The same letter over two averages means no significant difference between them ( $p>0.05)$; if in two compared averages the letter is not repeated, then the averages differ significantly $(p<0.05)$. The results obtained in each group were compared using analysis of variance and the post-hoc Tukey test. 


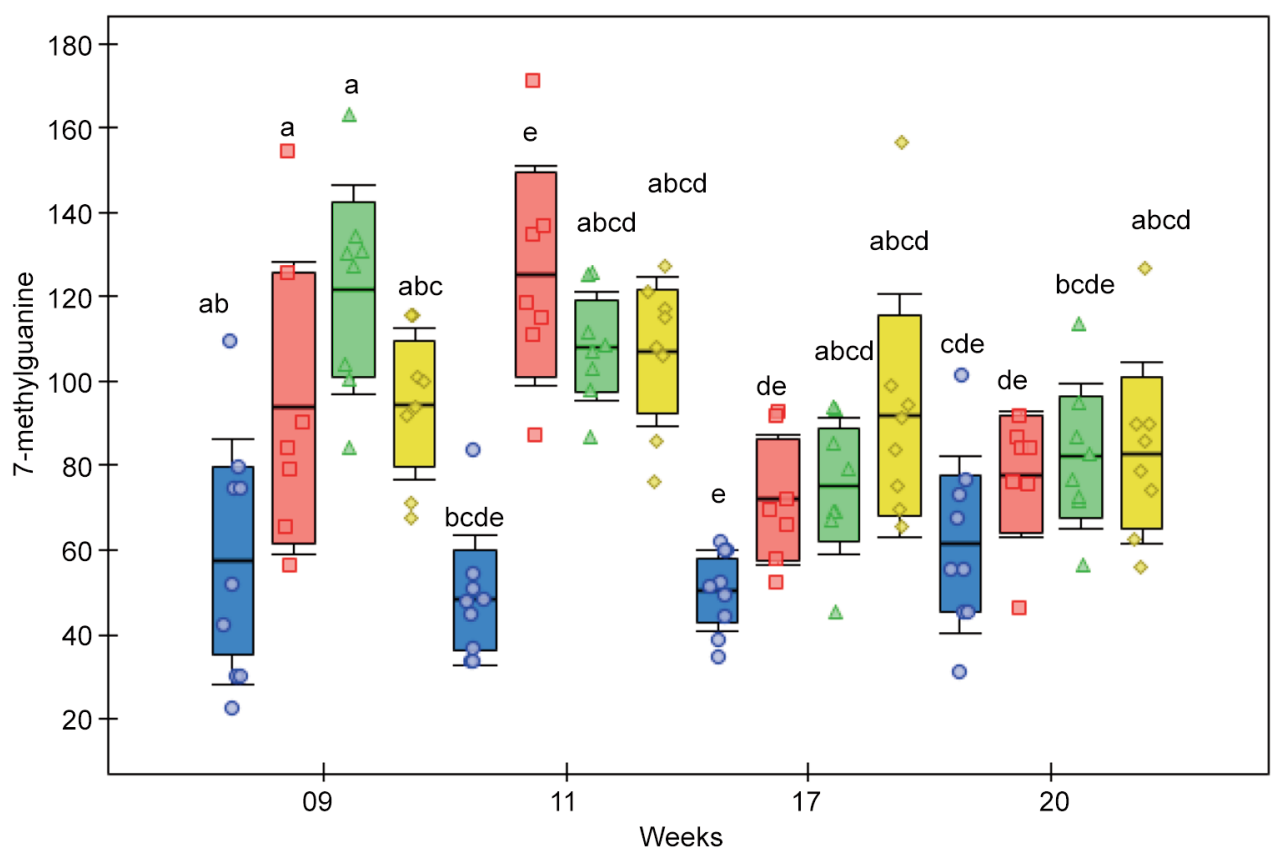

Figure 11. The effect of nano-, micro- and macro-genistein on the kinetics of changes $\left(9^{\text {th }}, 11^{\text {th }}, 17^{\text {th }}, 20^{\text {th }}\right.$ week of rat's life) in the levels of 7 methylguanine ( $\mu \mathrm{g} / \mathrm{mg}$ creatinine) in the urine of rats treated DMBA. Standard: blue circles, Macro:- red squares, Micro: green triangles, Nano: yellow diamonds. The same letter over two averages means no significant difference between them ( $p>0.05)$; if in two compared averages the letter is not repeated, then the averages differ significantly $(p<0.05)$. The results obtained in each group were compared using analysis of variance and the post-hoc Tukey test.

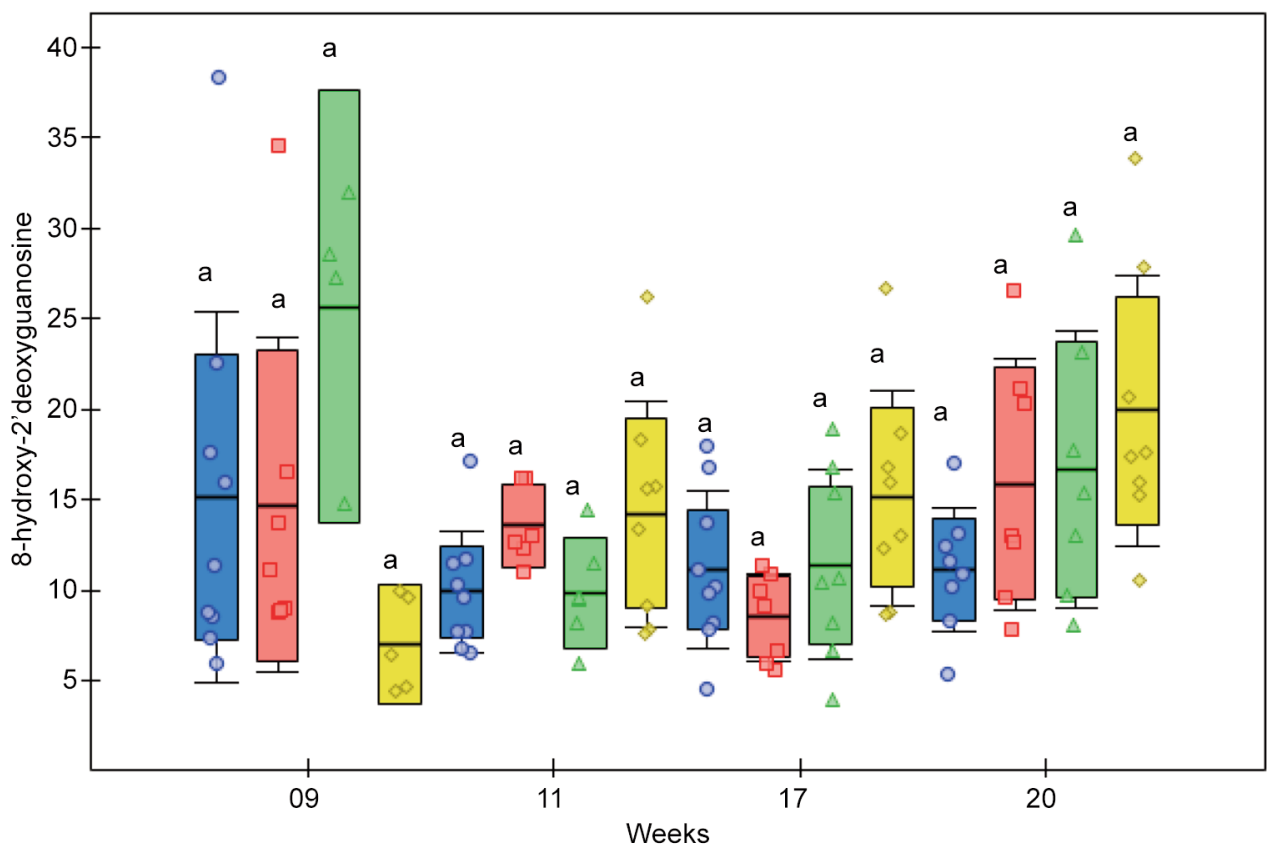

Figure 12. The effect of nano-, micro- and macro-genistein on the kinetics of changes $\left(9^{\text {th }}, 11^{\text {th }}, 17^{\text {th }}\right.$, $20^{\text {th }}$ week of rat's life) in the levels of 8 hydroxy-2'-deoxyguanosine (ng/mg creatinine) in the urine of rats treated DMBA. Standard: blue circles, Macro: red squares, Micro: green triangles, Nano: yellow diamonds. The same letter over two averages means no significant difference between them ( $p>0.05)$; if in two compared averages the letter is not repeated, then the averages differ significantly $(p<0.05)$. The results obtained in each group were compared using analysis of variance and the post-hoc Tukey test. 


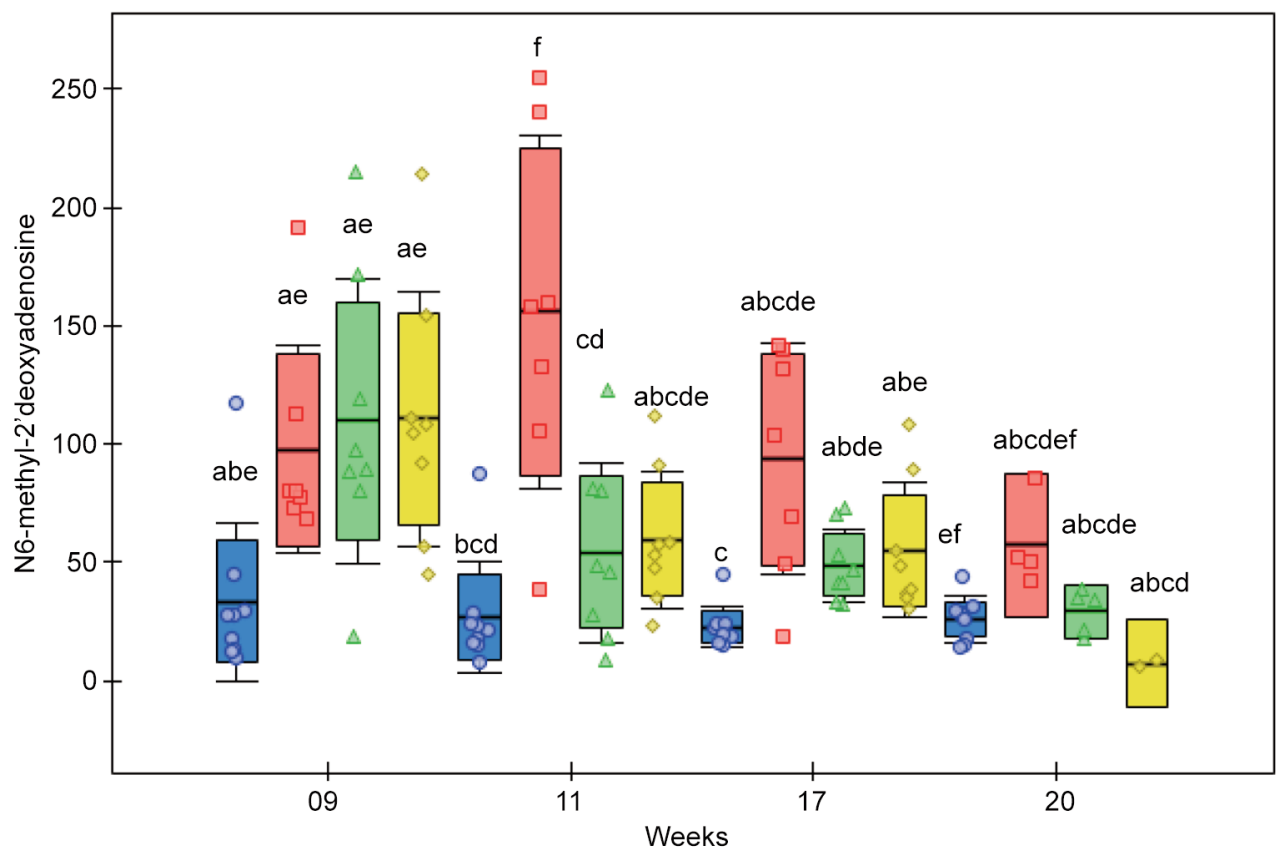

Figure 13. The effect of nano-, micro- and macro-genistein on the kinetics of changes $\left(9^{\text {th }}, 11^{\text {th }}, 17^{\text {th }}\right.$, 20 th week of rat's life) in the levels of N6methyl-2'deoxyadenosine ( $\mathrm{ng} / \mathrm{mg}$ creatinine) in the urine of rats treated DMBA. Standard: blue circles, Macro: red squares, Micro: green triangles, Nano: yellow diamonds. The same letter over two averages means no significant difference between them ( $p>0.05)$; if in two compared averages the letter is not repeated, then the averages differ significantly $(p<0.05)$. The results obtained in each group were compared using the analysis of variance and the post-hoc Tukey test.

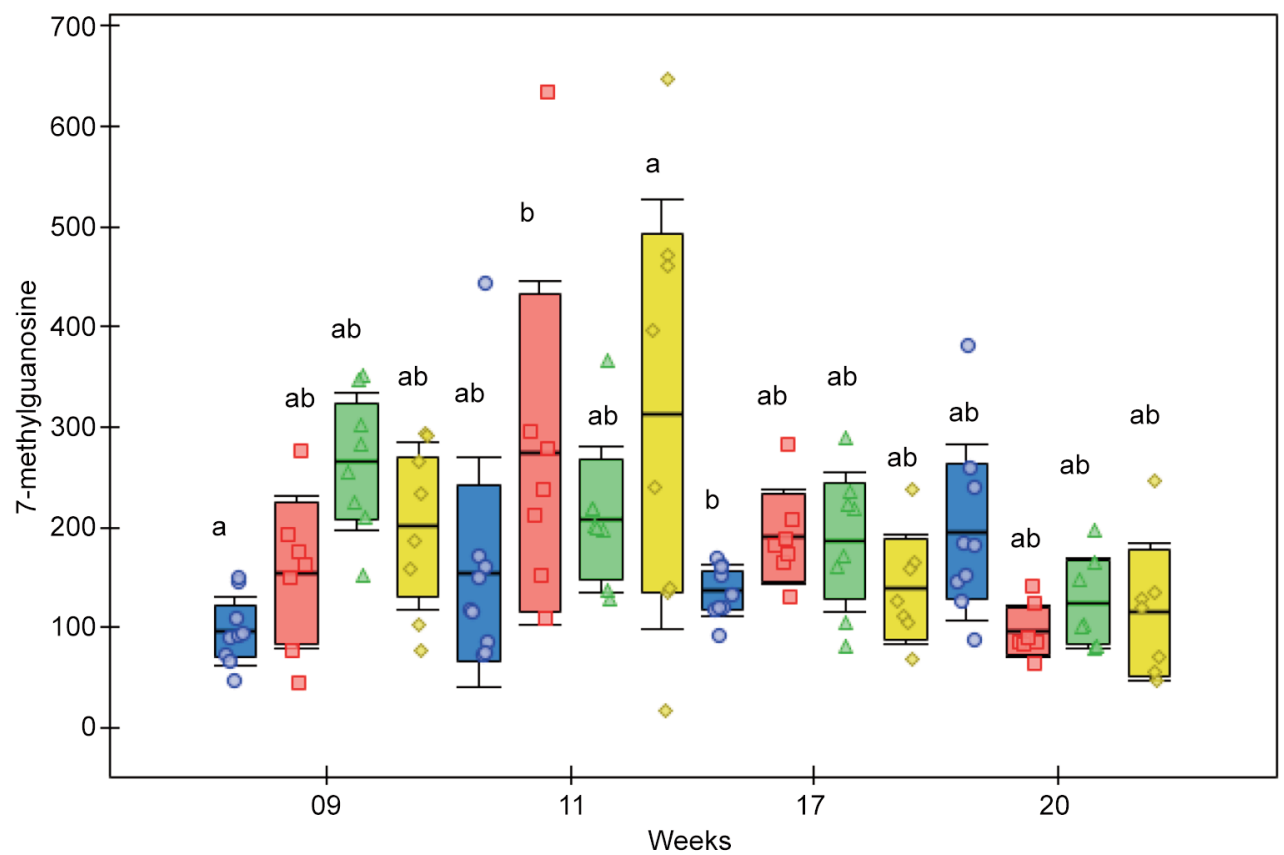

Figure 14. The effect of nano-, micro- and macro-genistein on the kinetics of changes $\left(9^{\text {th }}, 11^{\text {th }}, 17^{\text {th }}\right.$, $20^{\text {th }}$ week of rat's life $)$ in the levels of 7 methylguanosine (ng/mg creatinine) in urine of rats treated DMBA. Standard: blue circles, Macro: red squares, Micro: green triangles, Nano: yellow diamonds. The same letter over two averages means no significant difference between them $(p>0.05)$; if in two compared averages the letter is not repeated, then the averages differ significantly $(p<0.05)$. The results obtained in each group were compared using analysis of variance and the post-hoc Tukey test. 
methyladenine was also observed between weeks 11 and 20 $(p=0.04)$ in the nanogenistein-supplemented group (Figure 8).

The effect of nano-, micro- and macro-genistein on the kinetics of changes $\left(9^{\text {th }}, 11^{\text {th }}, 17^{\text {th }}, 20^{\text {th }}\right.$ week of rat's life) in the levels of 1-methylguanine ( $\mathrm{ng} / \mathrm{mg}$ creatinine) in the urine of rats treated with DMBA. Highly significant $(p<0.0001)$ differences between the groups were found, including persistently high levels of the methyl derivative in rats that received diets supplemented with macro-, micro- and nanogenistein. The differences between the measurement dates were not significant $(p=0.0533)$. It was found that in the initial period (week 9 and 11) the concentration of urinary 1-methylguanine was significantly lower in the control group compared to groups supplemented with micro- and nanogenistein $(p>0.05)$. Similar results were observed at week 11 in the case of rats supplemented with macro-, micro- and nano- genistein (as compared with rats that received only standard diet) $(p>0.05)$. At week 17, rats supplemented with nanogenistein were characterized by significantly higher levels of the urinary 1-methylguanine than rats without supplementation. Moreover, a statistically significant decrease in the concentration of 1-methylguanine was observed in the group supplemented with microgenistein between week 9 and week $17(p=0.04)$ (Figure 9).

The effect of nano-, micro- and macro-genistein on the kinetics of changes $\left(9^{\text {th }}, 11^{\text {th }}, 17^{\text {th }}, 20^{\text {th }}\right.$ week of rat's life) in the levels of 1-methyladenosine ( $\mu \mathrm{g} / \mathrm{mg}$ creatinine) in the urine of rats treated DMBA. Highly significant $(p<0.0001)$ differences between groups and $(p=0.0102)$ between weeks of measurements were found. The rats receiving only standard diet were characterized by lower content of 1methyladenosine in the urine at week 9 in comparison with the rats supplemented with microgenistein $(p<0.05)$. Statistically significant differences between the groups were observed at week 11; rats fed only with standard diet (without supplementation) had a lower concentration of urinary 1-methyladenosine in comparison with the rats supplemented with macro-, micro- and nano-genistein $(p<0.05)$. At weeks 17 and 20, the results of all groups did not differ significantly $(p>0.05)$. Moreover, a statistically significant decrease in the concentration of 1methyladenosine was observed in the group of rats supplemented with microgenistein between week 9 and week $17(p=0.01)$ (Figure 10).

The effect of nano-, micro- and macro-genistein on the kinetics of changes $\left(9^{\text {th }}, 11^{\text {th }}, 17^{\text {th }}, 20^{\text {th }}\right.$ week of rat's life $)$ in the levels of 7-methylguanine ( $\mu \mathrm{g} / \mathrm{mg}$ creatinine) in the urine of rats treated with $D M B A$. Highly significant differences between the groups and $(p<0.0001)$ between measurement dates $(p<0.0001)$ were found. At week 9 , rats that received only standard diet had a significantly lower concentration of 7-methylguanine in urine compared to rats supplemented with micro- and nano-genistein. A similar trend was also observed at week 11, where the concentration in the "standard" group was significantly lower than those in the macro-, micro-, and nano-genistein supplementation groups. At week 17, rats supplemented with nanogenistein were characterized by significantly higher levels of 7methylguanine than the rats without any supplementation. However, at week 20 concentration of 7-methylguanine did not differ significantly between the groups $(p>0.05)$. In addition, in rats supplemented with microgenistein, the concentration of 7-methylguanine in the urine was significantly reduced both between week 9 and 17 weeks $(p=0.001)$ and between week 9 and $20(p=0.040)$ (Figure 11).

The effect of nano-, micro- and macro-genistein on the kinetics of changes $\left(9^{\text {th }}, 11^{\text {th }}, 17^{\text {th }}, 20^{\text {th }}\right.$ week of rat's life) in the levels of 8-hydroxy-2'-deoxyguanosine ( $\mathrm{ng} / \mathrm{mg}$ creatinine) in the urine of rats treated with DMBA. No significant differences $(p=0.3497)$ between groups or between measurement dates were observed $(p=0.3228)$ (Figure 12).

The effect of nano-, micro- and macro-genistein on the kinetics of changes $\left(9^{\text {th }}, 11^{\text {th }}, 17^{\text {th }}, 20^{\text {th }}\right.$ week of rat's life) in the levels of N6-methyl-2'deoxyadenosine (ng/mg creatinine) in the urine of rats treated with $D M B A$. Highly significant differences between the groups $(p<0.01)$ and between measurement dates $(p<0.01)$ were found. At week 9 the concentration of N6-methyl-2'deoxyadenosine in the urine of rats fed standard diet was significantly lower than in the group of animals supplemented with microgenistein. Also, at weeks 11 and 17, the concentration of N6-methyl2 'deoxyadenosine in the group of animals fed a standard diet were significantly lower than its concentration in the group supplemented with macrogenistein $(p<0.01)$. At week 20 , the concentration of N6-methyl-2'deoxyadenosine in the urine of rats did not differ significantly between groups $(p>0.05)$. Moreover, a significant decrease in N6-methyl2 'deoxyadenosine urinary concentration was observed in micro- and nano-genistein supplemented groups over time. The abovementioned change occurred between week 9 and 11 in the microgenistein group and between week 17 and 20 in the nanogenistein supplemented group ( $p<0.01$, Figure 13).

The effect of nano-, micro- and macro-genistein on the kinetics of changes $\left(9^{\text {th }}, 11^{\text {th }}, 17^{\text {th }}, 20^{\text {th }}\right.$ week of rat's life) in the levels of 7-methylguanosine ( $\mathrm{ng} / \mathrm{mg}$ creatinine) in the urine of rats treated with DMBA. No significant differences were found between the groups $(p>0.05)$, while highly significant differences were found between the measurement dates $(p<0.01)$. In addition, a statistically significant reduction in urinary 7-methylguanosine levels was observed 
between week 11 and week 17 in rats that were supplemented with macrogenistein $(p=0.006)$. A decrease in the methyl derivative was also observed in the urine of rats supplemented with microgenistein $(p=0.01)$. In contrast, in the group of rats subjected to the standard diet, an increase in urinary 7-methylguanosine concentration was observed between week 9 and week $20(p=0.01)$ (Figure 14).

\section{Discussion}

Carcinogenesis is accompanied by epigenetic changes. They may be characterized by focal hypermethylation and global hypomethylation. Each of these mechanisms plays an essential role in carcinogenesis. Hypomethylation, which occurs mainly in repetitive regions, is a carcinogenic process; it promotes gene instability, causing erroneous chromosome segregation during cell division (20-22). Hypermethylation may lead to silencing of key tumour suppressors and regulatory regions in the genome, which leads to dysregulation of cell growth and changes in response to cancer therapy $(20,23)$. In this study, we investigated the effect of the isoflavonoid found in soybean genistein on cancer cells. Soybeans are the most widely used, least expensive, and least caloric way to get large amounts of protein. Soy foods have a lot of isoflavones including genistein, which are estrogen-like. Because their chemical structure is similar to $17-\beta$-estradiol, they bind to estrogen receptors and display higher affinity for ER- $\beta$ than for ER- $\alpha$. Moreover, they can influence the activation of both genomic and nongenomic estrogen signaling pathways. It is important to note that the tumors induced by the carcinogen 7,12dimethylbenz[a]anthracene are mostly ER/PR+, as in humans $(24,25)$. The results regarding the effect of genistein are inconclusive, some of them show protective effects and others harmful effects. Nevertheless, the tumorigenic properties of soy isoflavones are well documented in breast cancer cell lines and animal models and are largely associated with their estrogenic properties $(26,27)$. Estrogen can promote the development and metastasis of breast cancers, therefore, consumption of soy foods or soy isoflavones may be disadvantageous. Researchers from the Memorial Sloan Kettering Cancer Center and Weill Cornell Medical College, have shown that adding a moderate amount of soy to some women's diets may activate a gene that leads to cancer development $(28,29)$. Their research confirmed the concerns that soy may affect gene expression associated with breast cancer development. High plasma genistein was associated with a signature characterized by over-expression of FGFR2 and genes that drive the cell cycle and proliferation pathways $(28,29)$. Our results showed that the supplementation of animals with genistein causes an increase in the excretion of methylated derivatives in the urine of rats. The influence of genistein on the formation of methyl derivatives plays a particularly important role in the early stages of carcinogenesis. In the case of animals receiving only standard diet, the levels of methyl derivatives increased during the course of the study (O-methylguanosine, 1-methyladenosine, 7-methylguanine, 7-methylguanosine) or remained relatively low (3-methyladenine, 1-methylguanine, 7-methylguanine, N6-methyl-2'-deoxyadenosine). However, in the case of animals supplemented with various forms of genistein, the levels of the methylated derivatives were very high from the beginning. It is worth noting that the highest levels of the methyl derivatives were found in the urine of animals supplemented with genistein at 9 and 11 weeks of life, i.e., in the early stage of DMBA-induced neoplastic process. Such high levels of methyl derivatives indicate high cell proliferation. They can be associated with the development of the cancer process. It can be concluded that carcinogenesis was more intensive in rats that were supplemented with genistein. DNA methylation is known to be abnormal in all forms of cancer and carcinogenesis-related changes in DNA methylation can be detected with accuracy in cell-free DNA present in blood, feces, urine and other biological samples. Therefore, cancer-related changes in DNA methylation can be potentially clinically useful for the development of cancer biomarker assays. They would allow initial cancer detection and may be used to monitor treatment efficacy and patients throughout the disease. DNA methylation testing is very promising for the development of simple and specific methods for detecting cancer at an early stage (20). It has been shown that there is homology between the effects of DMBA on rats and estrogens, which can contribute to accelerating tumour development (30). It is also worth mentioning that one study described the occurrence of estrogen receptors after induction of breast tumours using DMBA (31). Considering the histopathological results and the concentration of methyl derivatives, it seems that nanogenistein stimulates cancer cells the most and tumours appear relatively quickly. In the group of animals supplemented with nanogenistein, the first tumours appeared as early as 14 weeks, 2 weeks earlier than in animals receiving only the standard diet and 3 weeks earlier than in animals supplemented with macro- and micro-genistein. The nanoparticles overcome biological barriers readily and enable prolonged blood circulation time, which, in effect, enhances the accumulation of nanoparticles in cancer cells. The nano form changes genistein bioavailability. The nano molecule, which was the smallest form of genistein studied in this study, probably changed the bioavailability. The bioavailability is defined in three basic steps: absorption, penetration into systemic circulation and use by the cells. Reduction of materials to the nano scale can sometimes lead to the development of new structural, phytochemical, electronic, and magnetic properties that are not present in larger sized particles comprised the same material. In comparison with 
their large counterpart particles can have novel/different physical properties such as an increased surface area to volume ratio, reactive sites, charge, shape, mobility and thermal properties (32). The form of particles can unambiguously change their properties and therefore, the nanogenistein effects on human physiology. For this reason, nanoparticles are ideally suited for the diagnosis and treatment of various diseases allowing earlier detection of pathological changes and more effective treatment of patients (33). However, considering the structure of genistein and its potential of intensifying the proliferation of cancer cells, the use of nanotechnology in our study had the opposite effect on the severity of cancer. What is interesting, in animals supplemented with microgenistein, although the first tumours appeared at week 17, a week later than in animals receiving only the standard diet, the incidence of tumours was $88 \%$, and the number of tumors per rat ranged from 0 to 3 , there was a statistically significant stimulation of tumour growth. The mass of the tumours in the animals receiving microgenistein was significantly higher compared to the mass of the tumours of animals receiving standard diet only, nanoand macro-genistein. Therefore, it is possible that the effect of genistein depends on the size of the particles. Even though we did not expect such results, none of the studied forms of genistein inhibited the development of the cancer process, and on the contrary, they stimulated cancer progression.

In summary, genistein contained in soy may increase the risk of developing breast cancer. Although, due to estrogenic activity, soy protein products are recommended as a natural alternative to estrogen drugs, many specialists consider that in some cases it may pose a potential risk to health (34). Earlier animal studies have shown that genistein can cause breast cancer (35). In addition, human studies have also provided disturbing results: in the case of a diet with soy protein, rich in this isoflavonoid, an increase in epithelial cells in the breasts, i.e., those that most often become cancer cells, has been observed (36). This article shows that genistein can modify the development of the neoplastic process by changing the methylation status of DNA. Further research is needed to understand the mechanism of action of different sizes of genistein particles on cancer cells and epigenetic alternations.

\section{Conclusion}

In this article, genistein has been shown to modify the development of neoplasms, and changes at the epigenetic level, among others, may play an important role in this process. It was observed that supplementation of animals with genistein causes an increase in the excretion of methylated derivatives in the urine of rats. The results of this study and the available literature may indicate stimulation of cancer cells depending on the size of genistein molecules.

\section{Conflicts of Interest}

All Authors confirm that there are no conflicts of interest to declare regarding this study.

\section{Authors' Contributions}

All Authors contributed equally to all aspects of this work.

\section{References}

1 Spagnuolo C, Russo GL, Orhan IE, Habtemariam S, Daglia M, Sureda A, Nabavi SF, Devi KP, Loizzo MR, Tundis R and Nabavi SM: Genistein and cancer: current status, challenges, and future directions. Adv Nutr 6(4): 408-419, 2015. PMID: 26178025. DOI: $10.3945 /$ an.114.008052

2 Li QS, Li CY, Li ZL and Zhu HL: Genistein and its synthetic analogs as anticancer agents. Anticancer Agents Med Chem 12(3): 271-281, 2012. PMID: 22043996. DOI: 10.2174/ 187152012800228788

3 Morris SM, Akerman GS, Warbritton AR, Patton RE, Doerge DR, Ding $X$ and Chen JJ: Effect of dietary genistein on cell replication indices in C57BL6 mice. Cancer Lett 195(2): 139-145, 2003. PMID: 12767521. DOI: 10.1016/s0304-3835(03)00155-1

4 Tuli HS, Tuorkey MJ, Thakral F, Sak K, Kumar M, Sharma AK, Sharma U, Jain A, Aggarwal V and Bishayee A: Molecular mechanisms of action of genistein in cancer: recent advances. Front Pharmacol 10: 1336, 2019. PMID: 31866857. DOI: 10.3389/fphar.2019.01336

5 Yang X, Yang S, McKimmey C, Liu B, Edgerton SM, Bales W, Archer LT and Thor AD: Genistein induces enhanced growth promotion in ER-positive/erbB-2-overexpressing breast cancers by ER-erbB-2 cross talk and p27/kip1 downregulation. Carcinogenesis 31(4): 695-702, 2010. PMID: 20067990. DOI: 10.1093/carcin/bgq007

6 Chen HH, Chen SP, Zheng QL, Nie SP, Li WJ, Hu XJ and Xie MY: Genistein promotes proliferation of human cervical cancer cells through estrogen receptor-mediated PI3K/Akt-NF-kB pathway. J Cancer 9(2): 288-295, 2018. PMID: 29344275. DOI: 10.7150/jca.20499

7 Helferich WG, Andrade JE and Hoagland MS: Phytoestrogens and breast cancer: a complex story. Inflammopharmacology 16(5): 219-226, 2008. PMID: 18815740. DOI: $10.1007 / \mathrm{s} 10787-$ 008-8020-0

8 Tonetti DA, Zhang Y, Zhao H, Lim SB and Constantinou AI: The effect of the phytoestrogens genistein, daidzein, and equol on the growth of tamoxifen-resistant T47D/PKC alpha. Nutr Cancer 58(2): 222-229, 2007. PMID: 17640169. DOI: 10.1080/ 01635580701328545

9 Spector LG, Xie Y, Robison LL, Heerema NA, Hilden JM, Lange B, Felix CA, Davies SM, Slavin J, Potter JD, Blair CK, Reaman GH and Ross JA: Maternal diet and infant leukemia: the DNA topoisomerase II inhibitor hypothesis: a report from the children's oncology group. Cancer Epidemiol Biomarkers Prev 14(3): 651-655, 2005. PMID: 15767345. DOI: 10.1158/1055-9965.EPI-04-0602

10 Zheng YF, Kong HW, Xiong JH, Lv S and Xu GW: Clinical significance and prognostic value of urinary nucleosides in breast cancer patients. Clin Biochem 38(1): 24-30, 2005. PMID: 15607313. DOI: 10.1016/j.clinbiochem.2004.09.021 
11 Sasco AJ, Rey F, Reynaud C, Bobin JY, Clavel M and Niveleau A: Breast cancer prognostic significance of some modified urinary nucleosides. Cancer Lett 108(2): 157-162, 1996. PMID: 8973589. DOI: 10.1016/s0304-3835(96)04393-5

12 Itoh K, Konno T, Sasaki T, Ishiwata S, Ishida N and Misugaki M: Relationship of urinary pseudouridine and 1-methyladenosine to activity of leukemia and lymphoma. Clin Chim Acta 206(3): 181-189, 1992. PMID: 1606704. DOI: 10.1016/00098981(92)90087-7

13 Zheng YF, Yang J, Zhao XJ, Feng B, Kong HW, Chen YJ, Lv S, Zheng $\mathrm{MH}$ and $\mathrm{Xu} \mathrm{GW}$ : Urinary nucleosides as biological markers for patients with colorectal cancer. World J Gastroenterol 11(25): 3871-3876, 2005. PMID: 15991285. DOI: 10.3748/wjg.v11.i25.3871

14 Watanabe S, Ichimura T, Fujita N, Tsuruzoe S, Ohki I, Shirakawa M, Kawasuji M and Nakao M: Methylated DNAbinding domain 1 and methylpurine-DNA glycosylase link transcriptional repression and DNA repair in chromatin. Proc Natl Acad Sci U.S.A. 100(22): 12859-12864, 2003. PMID: 14555760. DOI: $10.1073 /$ pnas. 2131819100

15 Yoon JH, Roy Choudhury J, Park J, Prakash S and Prakash L: Translesion synthesis DNA polymerases promote error-free replication through the minor-groove DNA adduct 3-deaza-3methyladenine. J Biol Chem 292(45): 18682-18688, 2017. PMID: 28939775. DOI: 10.1074/jbc.M117.808659

16 Boysen G, Pachkowski BF, Nakamura J and Swenberg JA: The formation and biological significance of N7-guanine adducts Mutat Res 678(2): 76-94, 2009. PMID: 19465146. DOI: 10.1016/j.mrgentox.2009.05.006

17 Rinne ML, He Y, Pachkowski BF, Nakamura J and Kelley MR: $\mathrm{N}$-methylpurine DNA glycosylase overexpression increases alkylation sensitivity by rapidly removing non-toxic 7methylguanine adducts. Nucleic Acids Res 33(9): 2859-2867, 2005. PMID: 15905475. DOI: 10.1093/nar/gki601

18 Xie Q, Bai Q, Zou LY, Zhang QY, Zhou Y, Chang H, Yi L, Zhu JD and Mi MT: Genistein inhibits DNA methylation and increases expression of tumor suppressor genes in human breast cancer cells. Genes Chromosomes Cancer 53(5): 422-431, 2014 PMID: 24532317. DOI: $10.1002 / \mathrm{gcc} .22154$

19 Zhang Y and Chen H: Genistein, an epigenome modifier during cancer prevention. Epigenetics 6(7): 888-891, 2011. PMID: 21610327. DOI: 10.4161/epi.6.7.16315

20 Klein CB and King AA: Genistein genotoxicity: critical considerations of in vitro exposure dose. Toxicol Appl Pharmacol 224(1): 1-11, 2007. PMID: 17688899. DOI: 10.1016/ j.taap.2007.06.022

21 Bloedon LT, Jeffcoat AR, Lopaczynski W, Schell MJ, Black TM, Dix KJ, Thomas BF, Albright C, Busby MG, Crowell JA and Zeisel SH: Safety and pharmacokinetics of purified soy isoflavones: single-dose administration to postmenopausal women. Am J Clin Nutr 76(5): 1126-1137, 2002. PMID: 12399289. DOI: $10.1093 /$ ajcn/76.5.1126

22 Mai Z, Blackburn GL and Zhou JR: Genistein sensitizes inhibitory effect of tamoxifen on the growth of estrogen receptor-positive and HER2-overexpressing human breast cancer cells. Mol Carcinog 46(7): 534-542, 2007. PMID: 17295235. DOI: $10.1002 / \mathrm{mc} .20300$

23 Hanahan D and Weinberg RA: Hallmarks of cancer: the next generation. Cell 144(5): 646-674, 2011. PMID: 21376230. DOI: 10.1016/j.cell.2011.02.013
24 Abba MC, Zhong Y, Lee J, Kil H, Lu Y, Takata Y, Simper MS, Gaddis S, Shen J and Aldaz CM: DMBA induced mouse mammary tumors display high incidence of activating Pik3caH1047 and loss of function Pten mutations. Oncotarget 7(39): 64289-64299, 2016. PMID: 27588403. DOI: 10.18632/oncotarget.11733

25 Kerdelhué B, Forest C and Coumoul X: DimethylBenz(a)anthracene: A mammary carcinogen and a neuroendocrine disruptor. Biochim Open 3: 49-55, 2016. PMID: 29450131. DOI: 10.1016/j.biopen.2016.09.003

26 Belinsky SA, Nikula KJ, Palmisano WA, Michels R, Saccomanno G, Gabrielson E, Baylin SB and Herman JG: Aberrant methylation of p16(INK4a) is an early event in lung cancer and a potential biomarker for early diagnosis. Proc Natl Acad Sci U.S.A. 95(20): 11891-11896, 1998. PMID: 9751761. DOI: $10.1073 /$ pnas.95.20.11891

27 Leclercq G and Heuson JC: Specific estrogen receptor of the DMBA-induced mammary carcinoma of the rat and its estrogenrequiring molecular transformation. Eur J Cancer 9(9): 675-680, 1973. PMID: 4372055. DOI: 10.1016/0014-2964(73)90010-8

28 Shike M, Doane AS, Russo L, Cabal R, Reis-Filho JS, Gerald W, Cody H, Khanin R, Bromberg J and Norton L: The effects of soy supplementation on gene expression in breast cancer: a randomized placebo-controlled study. J Natl Cancer Inst 106(9): dju189, 2014. PMID: 25190728. DOI: 10.1093/jnci/dju189

29 Bachanek I and Czauderna M: Izoflawony - struktura, aktywność biologiczna oraz metody ozna-czania przy użyciu wysokosprawnej chromatografii cieczowej. Wiadom Chem 68: 7-8, 2014.

$30 \mathrm{Li} \mathrm{Y,} \mathrm{Ahmed} \mathrm{F,} \mathrm{Ali} \mathrm{S,} \mathrm{Philip} \mathrm{PA,} \mathrm{Kucuk} \mathrm{O} \mathrm{and} \mathrm{Sarkar} \mathrm{FH:}$ Inactivation of nuclear factor kappaB by soy isoflavone genistein contributes to increased apoptosis induced by chemotherapeutic agents in human cancer cells. Cancer Res 65(15): 6934-6942, 2005. PMID: 16061678. DOI: 10.1158/0008-5472.CAN-04-4604

31 Gong L, Li Y, Nedeljkovic-Kurepa A and Sarkar FH: Inactivation of NF-kappaB by genistein is mediated via Akt signaling pathway in breast cancer cells. Oncogene 22(30): 4702-4709, 2003. PMID: 12879015. DOI: $10.1038 /$ sj.onc. 1206583

32 Satoh H, Nishikawa K, Suzuki K, Asano R, Virgona N, Ichikawa $\mathrm{T}$, Hagiwara $\mathrm{K}$ and Yano T: Genistein, a soy isoflavone, enhances necrotic-like cell death in a breast cancer cell treated with a chemotherapeutic agent. Res Commun Mol Pathol Pharmacol 113-114: 149-158, 2003. PMID: 15686114.

33 Caëtano B, Le Corre L, Chalabi N, Delort L, Bignon YJ and Bernard-Gallon DJ: Soya phytonutrients act on a panel of genes implicated with BRCA1 and BRCA2 oncosuppressors in human breast cell lines. Br J Nutr 95(2): 406-413, 2006. PMID: 16469160. DOI: 10.1079/bjn20051640

34 Liu B, Edgerton S, Yang X, Kim A, Ordonez-Ercan D, Mason T, Alvarez K, McKimmey C, Liu N and Thor A: Low-dose dietary phytoestrogen abrogates tamoxifen-associated mammary tumor prevention. Cancer Res 65(3): 879-886, 2005. PMID: 15705886.

35 Feinberg AP, Ohlsson R and Henikoff S: The epigenetic progenitor origin of human cancer. Nat Rev Genet 7(1): 21-33, 2006. PMID: 16369569. DOI: $10.1038 / \operatorname{nrg} 1748$

36 Curtis JR: The role of 7, 12 DMBA and three hormones in 7, 12 DMBA-induced rat mammary cancer: three hypotheses. Med Hypotheses 9(5): 489-507, 1982. PMID: 6818439. DOI: 10.1016/0306-9877(82)90018-4

Received March 26, 2021

Revised April 22, 2021

Accepted April 23, 2021 